\title{
SÔBRE OTOTYPHLONEMERTES DO BRASIL
}

\author{
por Diva Diniz Corrêa
}

\author{
(com 6 estampas)
}

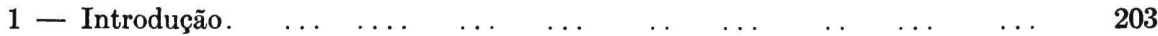

2 - Histologia do trato alimentar de $\begin{array}{llllllll}\text {. brevis } & \ldots & \ldots & \ldots & \ldots & \ldots & 204\end{array}$

3 - Alimentação do verme e atividade digestiva dos trechos isolados.. ... 207

4 - As clavas de Minot em Nemertini e Turbellaria $\quad \ldots \quad \ldots . \quad \ldots \quad 209$

5 - Descrição de $O$. erneba, sp. nov., e de $O$. parmula, sp. nov... .... 211

a) Diagnose das espécies novas $\ldots \ldots \ldots 211$

b) Comparação das mesmas com as espécies restantes do gênero. 213

c) Morfologia comparativa das Ototyphlonemertes brasileiras.... 214

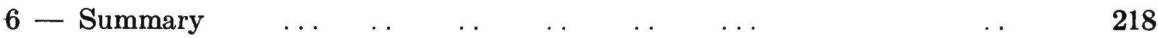

$\begin{array}{lllllllll}7 \text { - Bibliografia } & \ldots & \ldots & \ldots & \ldots & \ldots & \ldots & \ldots & 221\end{array}$

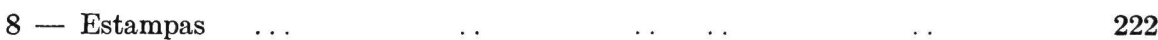

\section{1 - Introdução}

Analisei no ano passado (Corrêa 1949a, p. 183-190), a digestão de um Turbelário da Ordem Polycladida, examinando as fases sucessivas percorridas pela presa ingerida e os aspectos concomitantes das glândulas faríngeas e dos epitélios nas várias regiões do intestino. Verifiquei uma pré-digestão no intestino principal, mas a procedência dos fermentos ativos não consegui precisar pelo método histológico-comparativo. Bock (1925, p. 53-54) responsabilisou as células claviformes de Minot pela produção dêles, mas uma prova desta função das clavas não se pode depreender da análise histológica feita por êle. Surgiu-me então a idéia (p. 188) de isolar o intestino principal de grandes Policladidos, rico em clavas, e expôr alimentos habituais dêstes vermes à ação das células do intestino principal.

Não tendo conseguido, em experiências preliminares, resultados unívocos com êstes Turbelários, voltei a minha atenção para uma das espécies de Hoplonemertinos arenícolas do gênero Ototyphlonemertes, O. brevis (Corrêa 1948, p. 5). Nêstes há células eritrófilas concentradas no primeiro trecho do intestino. Desde Bürger (1895, p. 256) estas células, de conteúdo granuloso, foram tidas por glandulares. Böhmig (1929, p. 18, 64), autoridade em Turbelários e Nemertinos, comparou-as com as clavas de Minot dos Turbellaria.

Sem pretender concluir do aspecto histológico concordante, em função idêntica, pensei ser recomendável aproveitar essa concentração de clavas, rara entre Turbelários e Nemertinos, e isolar o trecho indicado. 
Naturalmente a manipulação técnica do intestino principal de grandes Polycladida é mais fácil que a de $O$. brevis, com $10 \mathrm{~mm}$. de comprimento máximo, mas por outro lado, a preponderância de clavas no intestino principal dos Policladidos não atinge, absolutamente, o mesmo gráu de $O$. brevis. Numerosas células epiteliais simples encontram-se entremeadas com as clavas no intestino principal dos Polycladida, ao passo que em $O$. brevis as clavas sobrepujam no trecho caudalmente contíguo ao estômago. A isolação da parte em questão e o exame das suas capacidades digestivas, comparadas com as das restantes, constituem o escopo do presente trabalho. Como premissa indispensável estudei a histologia do trato alimentar de $O$. brevis e ofereci ao verme presas variadas, para poder acompanhar histologicamente as fases sucessivas da digestão.

\section{2 - Histologia do trato alimentar de O. brevis}

No início tentei analisar as várias fases digestivas de vermes capturados na práia e fixados imediatamente depois. A seriação cronológica porém, apresentou dificuldades, principalmente porque o comprido tubo alimentar dos Nemertinos pode conter trechos sem presa alternando com outros, com presas em estados diversos de digestão e absorção. Por esta razão, não consegui, no início, saber se as massas incorporadas pertenciam à uma só ingestão ou não. Tive de obter um ponto fixo : a ingestão de uma presa em determinado momento. E verdade que não foi fácil fazer os vermes comer na instalação descrita na p. 207, mesmo oferecendo além de Poliquetos ainda Mysidacea e Hippolyte. Nas várias tentativas de alimentar os vermes consegui sempre um número muito pequeno de animais que aceitaram o alimento. Experimentei provocar nêles um estado de fome conservando-os durante vários dias e até semanas em bacias com areia, sem alimento. Todavia, também êstes vermes não comeram em maior número. Não foi possível eliminar da areia a fauna acompanhadora, p. e. Poliquetos e Turbelários microscópicos, ou também Protozoos (Coe 1943, p. 197), e assim, explica-se porque todos os vermes não se interessam pela presa em determinado momento.

Sucessivamente porém reuni suficiente material de animais que comeram sob a minha observação. Justamente a dificuldade que experimentei em arranjar um número suficiente dêstes vermes, justifica a minha suposição de se tratar nêles de animais jejunos quando removidos para a placa de observação. Depois de ter analisado sucessões de digestão, cujo início, a ingestão, eu conhecia, entendi também as fases encontradas em vermes da práia fixados a esmo.

Partindo dêste estado jejuno como fase-padrão descrevo-o na base das Figuras 1-5. O estômago (Figs. 1-2) possue epitélio de superfície vilosa, densamente ciliado por cílios curtos. Entre as células epiteliais ciliadas distinguem-se dois tipos de glândulas: umas grandes, com núcleos na parêde, vazias nos cortes, às vêzes dispostas em cacho (Fig. 1, es), e outras menores, com conteúdo granuloso, eritrófilo (Fig. 2, es). No total as glândulas grandes são mais numerosas que as pequenas, mas pode haver dentro da mesma série de cortes alguns planos com maior abundância de glândulas vermelhas. 
A câmara de clavas, como chamo a primeira parte do intestino (Fig. 3), caracteriza-se por um epitélio de células altas, homogêneas, não ciliadas nos cortes, entremeadas com outras células (g), volumosas e numerosas, aproximadamente claviformes ou tubulosas, repletas de grânulos eritrófilos. O lume é constante, mas a sua forma pode variar de acôrdo com o estado de contração dos músculos intestinais anelares descritos por Bürger (1895, p. 257).

O intestino médio anterior (Fig. 4), isto é, a região subsequente à câmara, apresenta os mesmos tipos de células, mas o número das claviformes é menor e o das células epiteliais correspondentemente maior. O lume em geral é mais estreito que na câmara.

No intestino médio posterior (Fig. 5) o número das células claviformes diminue ainda mais e o lume tende a extinguir-se.

Vermes recém-alimentados apresentam o estômago sem alterações perceptíveis, dando-se o mesmo nas fases seguintes. Daí pode-se deduzir que êste trecho não atua na absorção. Com isto, não se exclue a participação dos produtos das glândulas estomacais na digestão, em trechos posteriores do trato alimentar. A rapidez com que o alimento de Prostoma græcense (Böhm.) passa do estômago ao intestino levou Reisinger $(1926$, p. 15) à comparação do estômago com uma faringe, isto é, um trecho do intestino de ingestão.

Os vermes usados no estudo da presente fase comeram durante mais ou menos $15^{\prime}$ Deixei decorrer $2^{\prime}$ entre o abandono do resto da presa, Misidáceos esmagados e o ato da fixação.

A câmara de clavas (Fig. 6) mostra imediatamente depois da ingestão do alimento abaixamento do epitélio que se torna nitidamente menor que o da Fig. 3. Isto interpreto como fase de secreção de substâncias digestivas. As clavas ainda não diminuiram numericamente, mas o seu conteúdo apresenta-se reduzido em comparação com o estado de repouso. As células epiteliais comuns também parecem ter produzido secreção, pois são mais baixas, sem que se note qualquer aumento da densidade do seu citoplasma. $\mathrm{O}$ conteúdo do lume ainda não se acha digerido, como se reconhece pela estriação dos músculos do Crustáceo ingerido. Também as brânquias do mesmo são ainda perfeitamente reconhecíveis.

Nos trechos subsequentes (Fig. 9) o abaixamento do epitélio em secreção é ainda mais pronunciado. As clavas teem de acompanhar esta diminuição da altura das células intestinais restantes. Como a maioria delas ainda não esvaziou o seu conteúdo, dispõe-se oblíqua ou até paralelamente ao plano da base do epitélio. $O$ aspecto da presa assemelha-se ao da contida na câmara. Algumas clavas já derramaram a sua secreção no lume intestinal.

A fase seguinte refere-se a vermes que permaneceram durante $15^{\prime}$ no alimento e foram fixados $5^{\prime}$ após o abandono da presa.

Quando se coloca êste animal recém-alimentado entre lâmina e lamínula êle mostra, através das camadas do corpo, cerdas do Poliqueto ingerido. Devido à compressão da lamínula elimina tufos de 6-8 cerdas misturadas com conteúdo intestinal. O trato alimentar do verme fixado apresenta-se nitidamente dividido em zonas vazias e outras repletas de alimento. A estas zonas correspondem estados histológicos diferentes dos vários trechos 
do epitélio intestinal. Deve-se esta subdivisão aos movimentos "aspiradores" (veja p. 207) exercidos pelo animal durante a ingestão da presa. As constrições intensas produzidas pelas séries de ondas que percorrem o corpo do Nemertino ocasionam um despedaçamento mecânico da presa ingerida e êstes bolos distribuem-se em zonas de dilatação, mormente em casos de ingestão de objetos grandes (Reisinger 1926, p. 15). Como a fixação foi realizada muito brevemente, não houve tempo suficiente para a homogeneização do conteúdo no lume, no momento em que $O$. brevis entra em calma após ter deixado o alimento. Vermes cujo intestino permaneceu por mais tempo com o alimento, chegam a igualar as diferenças zonares, mostrando preenchimento e absorção homogêneos.

$\mathrm{Na}$ câmara de clavas (Fig. 10) existe diminuição quantitativa da secreção das células glandulares eritrófilas. Avançam para o lume e tornam-se filiformes em direção à base do epitélio. Uma faixa estreita no ápice das células epiteliais acha-se provida de grânulos, evidentemente formados por partículas alimentícias absorvidas. O conteúdo já foi transportado mais para trás. Com grande regularidade encontrei câmaras com lume vazio e suas células epiteliais em fases de absorção.

No trecho seguinte, intestino médio anterior, reconhece-se a digestão da presa no lume intestinal. A Fig. 7 mostra o começo da maceração do material ingerido, cabeça de um Poliqueto e as células intestinais já com alguns grânulos absorvidos. Fase semelhante é a da Fig. 8. O desenho reproduz um corte do intestino médio posterior em um trecho repleto de massas alimentares provindas de um Poliqueto. Mecânicamente acham-se despedaçadas; quimicamente ainda no início da digestão. O número de clavas sempre pequeno nesta região do trato alimentar, diminuiu ainda mais. Também as células epiteliais comuns apresentam-se muito baixas. Estes fatos permitem definir esta fase como de secreção máxima da parte do epitélio e início da digestão. Uma ligeira granulação já se nota no bordo livre das células epiteliais que começam assim a absorção do material digerido no lume. Digestão extra-celular mais avançada que nas Figs. 7-8 reconhece-se na Fig. 12. Grânulos eritrófilos passam dos tecidos desintegrados do Poliqueto para as células intestinais, permitindo, como em uma coloração vital, acompanhar o caminho do alimento.

Mais dissolvida ainda apresenta-se a presa na Fig. 15. Nesta região, intestino médio posterior, ainda não começou a absorção, mas do conteúdo intestinal reconhecem-se apenas algas (y) ingeridas acidentalmente pelo Nemertino, ou comidas pela presa, desconhecida no verme da Fig. 15. O que a nós interessa é a integridade das algas contrastando com a massa restante do conteúdo intestinal. Segundo Friedrich (1936, p. 59) ingora-se, se material vegetal é aproveitado por Nemertinos.

Já foi salientada a correlação muito regular entre fases de absorção e lume vazio na câmara das clavas. Não obstante, a intensidade da absorção ainda progride muito, além da fase da Fig. 10. Deve-se isto aos movimentos anti-peristálticos do intestino que podem ser observados no verme vivo. Entra desta forma, material que foi digerido no lume do intestino médio, na câmara (Fig. 11), e aí é absorvido. As células do epitélio expandem-se nos seus bordos livres, aumentando a sua superfície, pela formação de lóbulos dilatados, ao encontro do quimo. O material absorvido entumesce 
as células, entre as quais as clavas se conservam individualizadas, mas de tamanho reduzido, e a grande distância do bordo livre do epitélio.

No fim da absorção (Fig. 13) as clavas começam a recuperar a sua posição perto da superfície epitelial, e aí reassumirão volume idêntico ao da fase jejuna. As células epiteliais delimitam-se contra o lume, incumbindo-se da digestão ou assimilação dos grânulos absorvidos. Estes preenchem-nas totalmente. Não pretendo tentar a análise dos processos inter-celulares. Constato apenas uma diferença dos grânulos nas fases das Figs. 11 e 13. Na primeira, em que o epitélio emite estruturas semelhantes a vilosidades os grânulos são mais dissociados, na segunda são mais concentrados, maiores.

O quadro da câmara de clavas com epitélio completamente repleto de matéria alimentar (Fig. 13) repete-se, em fase correspondente, ao longo do intestino inteiro. Vê-se isto pela Fig. 14. As únicas diferenças residem no número de clavas, normalmente menor no intestino médio posterior, e na ausência de lume. Mas, como o último nem sempre se apresenta na fase jejuna, é insignificativo, se êle aparece ou oblitera-se nas várias fases digestivas. $\mathrm{O}$ verme representado nas Figs. 13-14 apresentou o tecido intestinal, da câmara até ao início do curto reto, alto e uniformemente cheio de esférulas alimentares arredondadas, relativamente grandes. Com a diminuição sucessiva destas inclusões o epitélio volta pouco a pouco à altura da fase jejuna, aumentando gradativamente o volume das clavas.

\section{3 - Alimentação do verme e atividade digestiva dos trechos isolados}

Para acompanhar o processo da procura e ingestão de alimento, até agora raramente observado em Nemertinos (Friedrich 1936, p. 59), procedi da seguinte forma : Cêrca de 20 vermes de $O$. brevis recém-trazidos para o laboratório, eram colocados n'água em uma placa de Petri (11 cms. de diâmetro), com fundo áspero obtido por esmerilhamento do vidro. Usei como alimento fragmentos de Poliquetos cortados no momento da oferta aos animais. $\mathrm{O}$ diâmetro da presa era aproximadamente igual ao de $O$. brevis.

Depois de certo tempo, alguns Nemertinos aproximaram-se ao alimento. Seguiu-se à aproximação a evaginação muito pronunciada da proboscis (Fig. 16) que tocou a superfície da presa, apanhando-a e dirigindo-a para a boca (Reisinger 1926, p. 12). As faces prediletas foram sempre as extremidades do fragmento obtidas pelo corte. Tendo a tromba atingido o alimento é o estilete principal injetado e firmemente instaladolno ponto da injeção. Como as presas consistiam em fragmentos de animais vivos, em bom estado, êstes reagiram sempre, como no material de Wilson (1900, p. 107) e, algumas vêzes o Nemertini perdia o contacto com êles. Em geral, porém, a primeira tentativa do agressor já era bem sucedida. Não vi no meu material nenhum caso de enrolamento da tromba ao redor da presa como em Prostoma græcense ao ingerir um fino Chaetogaster (Reisinger 1926, p. 14).

Os Nemertinos realizam movimentos que eu chamo aspiradores (Fig. 20) durante os quais séries de ondas percorrem sucessivamente o corpo do predador (Coe 1943, p. 213). No momento de apanhar a presa os Nemer- 
tinos encontram-se em máximo estado de distensão $(12 \mathrm{~mm}$.) e com a tromba evaginada. Durante a ingestão (Figs. 16-17) recolhe-se a tromba, com a presa na sua extremidade, e o diâmetro do corpo dilata-se para a recepção e deglutição do alimento. Durante êste processo o corpo do verme apresenta profundas alterações na forma (Fig. 20).

Em O. brevis que é um animal háptico (Corrêa 1949, p. 4) êste movimento é facilitado pela placa caudal firmemente colada ao substrato.

Os movimentos ondulatórios do corpo do verme são verificados durante a injeção na presa do veneno da glândula do estilete. Quero lembrar que em certos Anopla, a secreção cutânea paralisa a presa (Wilson 1900, p. 108).

Para a penetração do alimento no trato alimentar de $O$. brevis alarga-se pronunciadamente a boca ; o diâmetro desta ultrapassa ao da presa. Devido à transparência das camadas do corpo notam-se as acículas dos parapódios do Poliqueto deglutido (Figs. 16-17). Com o auxílio da lupa vi o alimento deslisar dentro do intestino. Em geral, 2 ou 3 vermes disputavam o mesmo fragmento. Atuando os vários predadores, em direções contrárias, impossibilitaram fosse a presa deglutida por um dêles. Nêstes casos, o conteúdo do fragmento do Poliqueto passou aos tratos alimentares dos Nemertinos por sucção. O máximo de tempo permanecido por um verme em ação de comer foi de $30^{\prime}$

Todos os vermes que comeram foram fixados para ulterior estudo histológico do trato digestivo. Ciente da digestão rápida dos Nemertinos (Coe 1943, p. 198), deixei decorrer apenas $15-45^{\prime}$ entre o abandono da presa e o ato da fixação.

Ofereci também aos vermes outros alimentos como Anfípodos totais, levemente esmagados e seguindo a Coe (1943, p. 197) fígado fresco, mas mesmo vermes com intestino vazio não reagiram a estas presas.

Como foi dito (p. 204) o meu problema central era examinar a capacidade digestiva dos vários trechos do intestino. A concentração das células glandulares eritrófilas no primeiro trecho do intestino torna esta região mais escura. Devido a isto foi fácil, sob a lupa, isolar três trechos do trato digestivo. A primeira cisura foi feita no limite entre estômago e câmara de clavas, a segunda, na zona posterior à câmara de clavas, em que estas não se acham mais concentradas. Obtive assim um primeiro trecho que chamo anterior. Abrange o esôfago e o estômago. A parte seguinte, o trecho médio contém a seç̧ão de clavas concentradas. A parte posterior compõe-se do intestino médio anterior e posterior, com poucas clavas, e do curto reto inclusive o anus.

Cêrca de 12-15 fragmentos do mesmo tipo eram colocados em lâminas com pequena gôta de água do mar. Cobri cada grupo com uma lamínula e exerci ligeira pressão sôbre a mesma esmagando os fragmentos, até conseguir esvasiamento do conteúdo das células do trato alimentar. Em seguida levantei as lamínulas e acrescentei à preparação algumas fibras musculares estriadas de Armadillidium vulgare Latr. (Crustacea Isopoda). Cobertas novamente com lamínulas foram tôdas as preparações colocadas em microscópios.

As experiências repetidas várias vêzes deram sempre resultados absolutamente concordantes e definitivos. 
Observei o processo durante $\mathbf{2 4}$ horas, a uma temperatura média de $19^{\circ} \mathrm{C}$. Os efeitos já eram distintos depois de 1 hora de observação e extremamente nítidos após 2 ou 4 horas. A clareza dos resultados possibilita uma exposição simples.

A lâmina que continha as partes do intestino, ricas em células claviformes, apresentou um total desaparecimento da estriação da fibra muscular, certamente devido à ação digestiva do conteúdo das referidas células. A parte posterior do intestino também digeriu perceptivelmente, mas muito menos rápida $\mathrm{e}$ intensamente que a média. $\mathrm{O}$ trecho anterior não alterou a estriação da fibra muscular durante o tempo da observação. Nos casos positivos, a fibra muscular não somente perdeu as estrias, mas desintegrou-se paulatinamente, liquefazendo-se em parte.

Usei como contrôle tôdas as vêzes uma quarta lâmina que continha somente a fibra estriada de $A$. vulgare. Em 24 horas ela permaneceu inalterada.

\section{4 - As clavas de Minot em Nemertini e Turbellaria}

O trato alimentar de Ototyphlonemertes brevis abrange as seguintes partes: a) esôfago ; b) estômago ; c) a região de clavas acumuladas ; d) o intestino médio dividido em anterior e posterior e o reto.

Os elementos do estômago são: células ciliadas e glândulas de dois tipos diferentes (Figs. 1-2, es). A região de clavas acumuladas compõe-se das células claviformes, de secreção granulosa eritrófila (Fig. 3, g) e de células intestinais comuns. No intestino médio (Figs. 4, 5) encontram-se os mesmos tipos celulares da região anterior, variando apenas o número das células glandulares eritrófilas.

Ototyphlonemertes brevis alimenta-se de Crustáceos e Poliquetos. Na ingestão de fragmentos de Poliquetos, o Nemertino apanha a presa por intermédio de sua tromba evaginada (Fig. 19).

Pela separação de três trechos 1) esôfago e estômago, 2) a região das clavas, 3) intestino restante, conseguiu-se verificar o seguinte : o primeiro trecho não digere ; o segundo trecho decompõe musculatura de Crustáceos ràpidamente. $\mathrm{O}$ terceiro trecho digere também, mas muito menos ràpidamente que o segundo. As células claviformes revelam-se, desta forma, como produtoras dos fermentos ativos para a digestão no lume intestinal. Esta pré-digestão ou digestão extra-celular é seguida pela intra-celular, das substâncias absorvidas, realizada nas células intestinais simples.

$O$ pêso inherente à experiência não deve levar à generalização da função das células claviformes, como foi aqui constatada em um Nemertino, para outros grupos de animais, como p. ex. os Turbelários. Na vastíssima literatura sôbre a digestão dêstes últimos, constitue a função das clavas de Minot um dos pontos mais controvertidos. Remeto os interessados nesta matéria à resenha de Pérez González (1949, p. 285-296) e à minha (Corrêa 1949a, p. 183-190). Ao lêr mais trabalhos turbelariológicos, encontramos novas contradições. Assim Méhely (1930) considerou as clavas como armazenadoras de material de reserva, em conformidade com Willier, Hyman \& Rifenburgh (1925, p. 324) e Hyman (1946). Por outro lado, foram observadas modificações nas clavas, quando a presa recém-ingerida entra no 
trecho intestinal respectivo, em três ordens diferentes dos Turbellaria: Proseriata (Marcus 1949, p. 61), Polycladida (Corrêa 1949a, p. 187) e Temnocephalida (Pérez González 1949, p. 290). Relatei (l. c.) os resultados discordantes de Westblad e Willier, Hyman \& Rifenburgh, que concordam apenas em não atribuir função digestiva às clavas dos Tricladida Paludicola. As opiniões contraditórias dos pesquisadores das várias ordens dos Turbelários não significam, obrigatóriamente, observação incorreta de um dos grupos, pois existe na filogênese, ao lado da especialização, também a mudança de função (Remane 1948, p. 259).

Esta mudança de função poderia ter atingido também as glândulas faríngeas. Estas foram responsabilizadas por Westblad (veja Corrêa 1949a, p. 189) pela digestão extra-celular. Bresslau \& Reisinger (1928, p. 38) consideraram como órgãos homólogos a faringe simples ("pharynx simplex") dos Turbellaria e o primeiro trecho do trato alimentar dos Nemertinos, isolado nas minhas experiências, ou sejam esôfago e estômago, para êles "faringe e intestino estomacal" As glândulas faríngeas seriam, portanto, homólogas às glândulas estomacais. Estas revelaram-se não digestivas, nas minhas experiências. Isto, porém, não invalida a opinião de Westblad, nem a de Bresslau \& Reisinger, pois órgãos morfologicamente homólogos não precisam absolutamente ser fisiologicamente análogos. A definição da atividade digestiva dos componentes do trato alimentar de Ototyphlonemertes brevis não torna excusadas outras, relativas às várias ordens dos Turbelários.

A homologia mencionada no último parágrafo sugere um rápido exame da posição dos Nemertini e dos Turbellaria no Sistema. Vogt (1851, p. 185-209) incluiu os dois grupos como ordens, na classe Platyhelmia. A terminologia modificou-se, falando-se hoje no "phylum" ou "cladus" Platyhelminthes, em que Turbellaria e Nemertini figuram como classes, ao lado dos Trematoda e Cestoidea. Existem divergências, talvez pouco importantes, quanto às relações entre as entidades dos Platyhelminthes ; Bürger (1907, p. 472) e, com certas restrições também Coe (1943, p. 222) acentuaram relações especialmente estreitas entre Turbellaria e Nemertini, ao passo que Bresslau \& Reisinger (1928, p. 34) reunem Turbellaria, Trematoda e Cestoidea em um "sub-cladus" (Euplatyhelminthes), afastando os Nemertini como representantes de um outro "sub-cladus", Rhynchocoela. Friedrich (1935, p. 370-371) duvida da possibilidade de manter Nemertini e Turbellaria no mesmo filo. Considera os últimos primariamente parenquimáticos, os primeiros secundàriamente parenquimáticos, como são os Hirudinea. Nos Turbellaria a cavidade do corpo (esquizocela) corresponderia ao blastocela; nos Nemertini, seria um deuterocela substituído pelo parênquima.

Com isto, Friedrich aproxima os Nemertini aos Annelida, no sentido de derivá-los dêstes últimos. Não se conhece bem o modo de formação do endomesoderma em Nemertinos e Turbelários (Bresslau \& Reisinger 1928, p. 47). Este ponto é evidentemente decisivo para a homologia ou diversidade da cavidade do corpo dos dois grupos.

A opinião de Friedrich a respeito da cavidade do corpo dos Nemertinos parece tão bem fundamentada quão é possível sem conhecimento do endomesoderma. A definição futura dos Turbelários não poderá prescindir dos pormenores da segmentação, concordantes em Polycladida e Polychæta, como foi muito bem ressaltado por Remane (1926, p. 749). Embora pro- 
vável que Nemertinos e Turbelários sejam "secundàriamente parenquimáticos" não existe prova disso e ainda menos a de serem uns secundária e os outros primàriamente parenquimáticos. A manutenção aqui advogada dos dois grupos no mesmo filo não obriga, certamente, a esperar função idêntica dos vários tipos de células intestinais.

\section{5 - Descrição de O. erneba, sp. nov., e de O. parmula, sp. nov.}

\section{a) Diagnose das espécies novas.}

Os robustos vermes de $O$. erneba (Fig. 26) são mais achatados que cilíndricos. A cabeça é ligeiramente abaulada e a cauda afilada e truncada. O comprimento de animais vivos é de $10-12 \mathrm{~mm}$. ; o de fixados, $5-6 \mathrm{~mm}$. A largura, uniforme, atinge $0,5 \mathrm{~mm}$. nos animais vivos ; $0,3 \mathrm{~mm}$. nos fixados. A distância entre a extremidade anterior do corpo e a dos gânglios cerebrais dorsais equivale à largura do corpo. A cor é creme, variando levemente com o estado alimentício dos animais.

O sulco cefálico transversal (h) é extremamente nítido e circunda todo o corpo do verme. Dorsalmente êle é mais largo e coloca-se posteriormente aos gânglios cefálicos dorsais, com o vértice voltado para a extremidade posterior do verme. Ventralmente é mais estreito e seu vértice colocado anteriormente atinge o nível médio dos gânglios dorsais. Os poros cerebrais (po) muito largos, são anteriores aos gânglios. Os órgãos cerebrais (o) são volumosos em comparação com o tamanho do verme. Sua câmara sensorial (r) mede $0,05 \mathrm{~mm}$. de diâmetro máximo. Olhos são ausentes. Os estatocistos ( $\mathrm{s}$, com $0,02 \mathrm{~mm}$. de diâmetro e forma ovóide, situam-se na face póstero-dorsal do gânglio ventral. Cada estatocisto contém um estatolito formado por três cristais esféricos contíguos.

$\mathrm{O}$ rincoceloma alcança aproximadamente a metade do corpo. A proboscis é bem forte, de diâmetro equivalente a um terço da largura do corpo do verme. Igualmente bem desenvolvido é o músculo retrator da proboscis. A câmara posterior (p) tem 1,2 $\mathrm{mm}$. de comprimento e $0,33 \mathrm{~mm}$. de largura. A vesícula bulbosa da câmara média (v) mede $0,25 \mathrm{~mm}$. ao comprido e aproximadamente o mesmo de largura. O diafragma (d) tem 0,42 $\mathrm{mm}$. de comprimento e largura de $0,39 \mathrm{~mm}$.. A base (k) do estilete principal é pronunciadamente piriforme. $\mathrm{O}$ comprimento dela é de quase 5 microns e largura de 2,5 microns. O estilete (u) de 10 microns ao comprido mede o dôbro do comprimento da base. Ao redor desta há volumosos pacotes de glândulas (ge). As bolsas dos estiletes accessórios situam-se anteriormente ao meio do estilete principal e incluem 6 estiletes de reserva (x) cada uma. A câmara anterior (a) com $0,30 \mathrm{~mm}$. de largura e $1 \mathrm{~mm}$. de comprimento, contém inúmeras papilas (Figs. 23, 24, 34, pa) dotadas cada uma de um bastonete rabdóide. Na eversão da tromba as papilas ficam como que penduradas na parede da câmara anterior.

Os sexos são separados. As gônadas são laterais, não alternadas com os indistintos divertículos intestinais.

O. erneba ocorre na Ilha de São Sebastião, na camada superficial da areia de granulação média, perto da linha da água. A zona de frequência máxima foi na linha da vasante, na primeira quinzena de novembro de 1949. Esta região é também intensamente habitada por Kata evelinæ (Turbellaria Proseriata). 
$\mathrm{O}$ verme de $O$. parmula (Fig. 28) mede de comprimento $3 \mathrm{~mm}$. ao vivo e 1,5 mm. depois de fixado. Possue corpo cilíndrico. Em vista dextro-sinistral há uma constrição do corpo ao nível dos gânglios cerebrais. A extremidade cefálica é ligeiramente abaulada. A largura máxima, que se encontra na altura posterior do cérebro, é de $0,2 \mathrm{~mm}$. no vivo e um pouco menor no fixado. Para trás, essa largura vai decrescendo gradativamente até terminar em cauda cuspidata. Esta possue como O. brevis (Corrêa 1948, p. 5) uma placa caudal (Fig. 31, z) mas não tão desenvolvida. Em vista dextro-sinistral ela apresenta-se como nadadeira. Inicia-se ventralmente, atrás do nível da inserção do músculo retrator da proboscis, por um aumento gradativo da altura da epiderme, e alcança a ponta caudal com a altura máxima de 19 microns. Ao atingir esta dobra-se para a frente e, após um percurso de 60 microns, volta bruscamente à epiderme de altura normal. A distância entre a extremidade anterior do corpo e a dos gânglios cerebrais dorsais é de $0,15 \mathrm{~mm}$. ou aproximadamente igual à largura máxima do corpo. A côr é branca à luz refletida.

Olhos são ausentes. O sulco cefálico transversal (h) é visível sôbre a metade anterior do cérebro. Os poros cerebrais (po) encontram-se anteriormente ao cérebro. Os órgãos cerebrais, restringem-se a estas pequenas reentrâncias da epiderme situadas ântero-lateralmente aos gânglios cerebrais. Nos cortes falta a continuação interna, a câmara sensorial. A julgar pelo único exemplar até agora disponível, $O$. parmula seria desprovida de órgãos cerebrais, como o é, seguramente $O$. brevis. Os cordões nervosos laterais (c) ressaltam-se muito no verme em preparação total. Os estatocistos (s), de forma esférica, acham-se situados na face póstero-dorsal do gânglio ventral. Cada estatocisto contém um estatolito formado por vários cristais esféricos reunidos em tôrno de um cristal central.

$\mathrm{O}$ rincoceloma estende-se até à metade do comprimento do corpo. A proboscis bem forte em comparação com as dimensões do verme, possue diâmetro máximo na altura do meio da câmara posterior, equivalente a quase metade da largura do corpo no mesmo trecho. A câmara posterior (p) tem $0,38 \mathrm{~mm}$. de comprimento e 75 microns de largura. A vesícula bulbosa da câmara média (v) mede tanto de largura quanto de comprimento, 55 microns. O diafragma (d) abrange 60 microns de largura máxima e as mesmas dimensões de comprimento. $\hat{\mathrm{E}}$ ligeiramente maior que a vesícula bulbosa. A base (k) do estilete principal é piriforme. O comprimento dela equivale ao comprimento do próprio estilete (u). Este é circundado em tôda sua extensão por marcas espiraladas. As bolsas dos estiletes accessórios contém cada uma 2-3 estiletes de reserva dotados das mesmas marcas espirais. A câmara anterior (a) com largura de 55 microns e comprimento de $0,25 \mathrm{~mm}$. mostra por transparência em óleo de cravo, o seu epitélio muito alto e êste possue as mesmas papilas descritas de $O$. erneba.

Os sexos são separados. As gônadas (j), em número de sete pares, encontravam-se bem desenvolvidas no momento da captura do verme.

Até agora conheço esta espécie apenas da areia de uma das práias da Ilha de São Sebastião. A descrição acima baseia-se em um exemplar e será completada pelo estudo de outros, colecionados depois da impressão do presente trabalho. 


\section{b) Comparação das esp cies novas com as restantes do gêneto.}

O. parmula é a única espécie brasileira conhecida que possue marcas espirais no estilete. Por esta razão já está separada das demais espécies do gênero, com exceção de $O$. spiralis Coe e $O$. pellucida Coe que possuem também êsse carater.

1) Em O. pallida pallida (Keferstein 1862, p. 60) a distância entre a ponta anterior e os poros cerebrais é igual ao duplo da largura do corpo. Em O. erneba esta medida corresponde à largura do corpo.

1a) O. pallida czerniavskyi Bürger (1904, p. 28). Cada estatocisto contém um par de grandes estatolitos e um de pequenos, ao passo que o estatolito de $O$. erneba é composto com grande regularidade de três glóbulos.

2) O. aurita aurita (Uljanin 1870 ; veja Bürger 1904, p. 28) tem o corpo atenuado nas duas extremidades; $O$. erneba afora a extremidade posterior mantém o mesmo diâmetro em tôda a extensão do corpo.

2a) O. aurita suchumica (Czerniavsky 1881; veja Bürger 1904, p. 28) distingue-se de $O$. erneba pelo mesmo caráter mencionado na espécie 2. Tanto $O$. aurita aurita como $O$. aurita suchumica são alaranjadas. $O$. erneba é côr de creme.

3) O. claparèdei (Du Plessis 1891, p. 414) tem $30 \mathrm{~mm}$. de comprimento na fase imatura ; $O$. erneba, quando madura, não ultrapassa $15 \mathrm{~mm}$.

4) O. aurantiaca (Du Plessis 1891, p. 415) é áurea (erneba: côr de creme); tem até $20 \mathrm{~mm}$. (erneba: $15 \mathrm{~mm}$.) e estatolitos bilobados (erneba: trilobados).

5) $O$. duplex Bürger (1895, p. 551) não ultrapassa $10 \mathrm{~mm}$. (erneba atinge $15 \mathrm{~mm}$.) e tem estatolitos em forma de haltere (erneba: trilobados).

6) O. macintoshi Bürger (1895, p. 551) atinge $30 \mathrm{~mm}$. de comprimento (erneba até $15 \mathrm{~mm}$.), tem cs estatolitos formados por vários cristais (erneba: trilobados) e não possue, provàvelmente, órgãos cerebrais (presentes em erneba).

7) O. brunnea brunnea Bürger (1895, p. 552) é acastanhada (erneba : côr de creme) e provida de duas manchas acastanhadas na cabeça (ausentes em erneba). O estatolito corresponde à espécie 5 .

7a) O. brunnea davidoffi Oxner (1907, p. XC) é também acastanhada.

8) O. spiralis Coe (1940, p. 288) atinge $50 \mathrm{~mm}$. de comprimento (erneba : $15 \mathrm{~mm}$. ; parmula: $3 \mathrm{~mm}$.), tem órgãos sensoriais laterais (ausentes em erneba e em parmula), cristas espiraladas nos estiletes (lisos em erneba) e vesícula da câmara média como simples canal (em erneba e parmula: vesícula em bulbo, típica do gênero).

9) O. pellucida Coe (1943, p. 266) possue estatolitos formados por vários cristais (erneba: trilobados) e estiletes marcados por um par de delicados sulcos espirais (em erneba : lisos), 2-4 estiletes de reserva em cada bolsa (em erneba até 6) e vesícula da câmara média como simples canal (em erneba e parmula : vesícula em bulbo, típica do gênero).

10) O. evelinæ Corrêa (1948, p. 2) atinge $30 \mathrm{~mm}$. de comprimento (erneba: $15 \mathrm{~mm}$.). Distingue-se ainda pela ausência de papilas com rabdóides na câmara anterior da proboscis (presentes em erneba), pela variação na forma e número dos estatolitos (constantes em erneba) e pelo estilete do mesmo comprimento que a base (em erneba o estilete tem o dôbro do comprimento da base).

11) O. brevis Corrêa (1948, p. 5) distingue-se da nova espécie pelo tamanho do corpo até $10 \mathrm{~mm}$. (erneba até $15 \mathrm{~mm}$.), pela ausência de órgãos cerebrais (presentes em erneba) e pelos estatolitos formados por mais de 10 cristais (em erneba : trilobados). 


\section{c) Morfologia comparativa das Ototyphlonemertes brasileiras.}

Nesta parte, além dos caracteres disjuntivos das várias espécies brasileiras, e dos pormenores do trato alimentar, de interesse especial no presente trabalho, considerei ainda os elementos de estrutura que Friedrich (1938, p. 233 e seg.) apontou como relevantes para o futuro agrupamento dos gêneros dos Monostilifera em famílias.

Com a descrição das duas novas espécies do gênero Ototyphlonemertes, O. erneba (Fig. 26) e O. parmula (Fig. 28), o número das espécies conhecidas dêste Hoplonemertini, ocorrentes no litoral Norte de São Paulo, equipara-se ao mesmo verificado no Mediterrâneo ocidental, a região até agora mais pesquizada nêste sentido.

As dimensões das quatro espécies oscilam entre os $3 \mathrm{~mm}$. do único exemplar de $O$. parmula e os $30 \mathrm{~mm}$. de $O$. evelinæ, como limites extremos para o comprimento. As outras duas espécies possuem dimensões intermediárias, $O$. erneba com $12 \mathrm{~mm}$. e $O$. brevis com $10 \mathrm{~mm}$.. A largura varia em tôdas as espécies entre 0,2-0,5 mm.. A côr é esbranquiçada ou levemente rosada.

Tôdas pertencem ao tipo de animais hápticos (Remane 1933, p. 185). $O$. brevis e $O$. parmula são dotadas de placa caudal fixadora. O erneba e $O$. evelinæ, quando tocadas por um estímulo enrolam-se ao redor de si mesmas em busca de um contacto. Com a ajuda dos cílios tôdas elas deslisam, mas nenhuma nada.

Integumento e parêde do corpo. As espécies presentes possuem a distribuição típica das camadas do corpo para a Ordem a qual pertencem (Coe 1943, p. 145). A epiderme já descrita de $O$. evelinæ (Corrêa 1948, p. 2) e de $O$. brevis (l. c., p. 6) apresenta-se com caracteres semelhantes em $O$. erneba (Fig. 27, e) e em 0 . parmula, havendo porém, nestas últimas, abundantes células eosinófilas na extremidade anterior do corpo. $\mathrm{Na}$ extremidade caudal há numerosos espaços claros correspondentes a glândulas esvaziadas. Em O. erneba há pacotes de glândulas epidérmicas aprofundadas. Ocupam o espaço entre a membrana basilar e a parêde do intestino ficando encravadas nas camadas de musculatura. A membrana basilar é fina.

A musculatura do corpo (Fig. 28, mu) é representada por um estrato fino de músculos anelares, adjacente à membrana basilar, seguido por um espêsso de músculos longitudinais. Pelo que consegui verificar os dois estratos musculares estendem-se em tôdas as espécies até à extremidade anterior. Em $O$. erneba a camada de músculos anelares é muito espêssa, correspondendo a um terço da espessura da longitudinal.

Pertence à musculatura o septo pré-cerebral (Fig. 18) constituído por feixes musculares (mt), os fixadores da tromba descritos de O. evelinæ (Corrêa 1948, p. 3) e presentes em O. erneba.

Fibras de tecido conjuntivo, metamericamente dispostas, estendem-se desde a extremidade caudal até à extremidade cefálica em $O$. erneba. Ligam a membrana basilar à parêde do intestino e, anteriormente ao cérebro, unem-se à parêde do rincodeo. Constituem estas fibras um verdadeiro esqueleto muito bem desenvolvido nesta espécie. 
O parênquima é extremamente abundante em duas das espécies presentes: $O$. brevis e $O$. erneba. Em O. evelinæ é muito escasso (Corrêa 1948, p. 2) mas a mesma indicação relativa a $O$. brevis (l. c., p. 6) acabo de corrigir. Em cortes de $O$. brevis e $O$. erneba veem-se grandes massiços parenquimáticos ocupando a maior parte do espaço compreendido entre as camadas de musculatura e o intestino. Teem o aspecto esponjoso, fibrilar e tingem-se em azul nos cortes corados com hematoxilina-eosina.

Células do parênquima penetram no epitélio intestinal (Fig. 29, q) e estomacal através do limite basilar dêles. Em cortes transversais encontram-se até 4-6 pacotes parenquimáticos contornando a parêde do intestino. Em cortes longitudinais vê-se a penetração e o longo percurso do parênquima dentro do epitélio intestinal. $O$ parênquima pode penetrar até nos gânglios cerebrais, assim como apresentar largas penetrações epidérmicas.

$\operatorname{Em} O$. brevis e $O$. erneba não foi possível verificar com exatidão a existência e o âmbito das glândulas cefálicas, em consequência da grande abundância de parênquima em tôda a extensão do corpo. Acrescenta ainda a semelhança histológica entre parênquima e glândulas cefálicas. Em $O$. evelinæ (Fig. 35, gc) as glândulas cefálicas ressaltam-se como duas faixas laterais ao rincodeo, abrindo-se na reentrância resultante da desembocadura dêste no orifício oro-proboscidial.

Canal digestivo. No rincodeo, anteriormente ao cérebro, começa o esôfago (Fig. 35, ef). O estômago, o setor seguinte, é quadrangular e bastante viloso em $O$. brevis. Suas células são densamente ciliadas e entremeadas com elas ocorrem células glandulares (Figs. 1-2, es). De forma alongada e menos viloso é o das outras espécies, mas como nestas, fortemente ciliado. $\mathrm{O}$ intestino médio, trecho compreendido entre estômago e o reto, não apresenta cílios nos cortes. Suas células alternam-se com outras, as células glandulares eritrófilas semelhantes às clavas de Minot dos Turbellaria. Em $O$. brevis, estas são concentradas na primeira parte do intestino (Fig. 3, g), que chamei por isso "câmara de clavas" A parte restante, sem acumulação de clavas, corresponde ao intestino propriamente dito das outras espécies. Subdivido-o em intestino médio anterior (Fig. 4) e posterior (Fig. 5). Em O. erneba as clavas são distribuídas em sua maioria no assoalho do intestino. Divertículos intestinais nítidos não existem. Em O. parmula há divertículos intestinais esboçados. A musculatura intestinal espessa-se posteriormente e aí constitue forte esfinter anal. Nenhuma das espécies descritas possue ceco. Vários exemplares de $O$. erneba mostraram quistos de Gregarina no seu intestino.

O exame de O. evelinæ (Corrêa 1948, p. 3) e de O. brevis (1. c., p. 6) sôbre a presença de órgãos excretores, tanto em cortes, quanto em animais vivos (Bürger 1899, p. 262), teve resultado negativo. Tentei verificá-los em $O$. erneba, que embora mais curta que $O$. evelinæ é dotada de constituição mais forte do corpo. Coloquei-a em solução fraca de azul de metileno para obter a coloração vital de eventuais protonefrídios. Todavia, em repetidas experiências, os resultados foram nulos e parece-me que órgãos excretores são realmente ausentes.

Proboscis. A proboscis de tôdas as espécies descritas compõe-se de quatro trechos : câmara anterior (Figs. 25, 26, 28, a), câmara média, subdividida em diafragma (d) e vesícula bulbosa (v) e câmara posterior (p). 
$\mathrm{O}$ rincoceloma não atinge nunca a extremidade caudal do corpo do verme. Por isso, o gênero poderia continuar a ser classificado entre os Prorhynchocœlomia (Bürger 1897, p. 17). Esta unidade não deve ser baseada no comprimento do rincoceloma (Brinkmann 1917, p. 158 ; StiasnyWijnhoff 1930, p. 233). Também no gênero Ototyphlonemertes a extensão do rincoceloma varia independentemente do tamanho especifico. Corresponde a $20 \%$ do comprimento do corpo em $O$. brevis, a $30 \%$ em $O$. evelinæ e a $50 \%$ em O. erneba e 0 . parmula. A sua parêde contém epitélio baixo e fibras musculares longitudinais e anelares. As fibras musculares são especialmente desenvolvidas em $O$. erneba assim como o músculo retrator da proboscis. Inserido na extremidade caudal da câmara posterior o retrator apresenta nesta espécie grossos feixes musculares.

A parêde da proboscis corresponde na disposição das suas camadas, ao esquema dos Hoplonemertini. Os nervos proboscidiais veem-se especialmente ao nível do diafragma. Aí existem de cada lado das bolsas dos estiletes accessórios, 3-4 nervos no corte transversal. As dimensões variáveis das diversas partes da proboscis já foram relatadas (Corrêa 1948, p. 3, 7) e (p. 211, 212).

Sistema vascular sanguineo. Este sistema é representado pelo conjunto de 2 vasos laterais que correm superposta e paralelamente aos cordões nervosos laterais (Figs. 3-5), bem visíveis em qualquer dos cortes transversais, e um vaso dorsal, supra-intestinal em todo o seu percurso. Em algumas preparações totais vê-se nitidamente a comissura cefálica dos vasos laterais (Fig. 26). A parêde dos vasos é nítida, espêssa e nucleada, como se vê nos cortes transversais. A delimitação da luz dos vasos é lisa.

Sistema nervoso. Dois pares de gânglios cerebrais (Figs. 26, 28, b) um dorsal colocado em posição mais cefálica e outro ventral situado caudalmente. Além da comissura interna entre os gânglios dorsais destaca-se em $O$. erneba também uma grossa comissura externa. O par de estatocistos coloca-se na face póstero-dorsal do gânglio ventral e daí sái o par de cordões nervosos laterais (c). O. brevis e $O$. parmula, apresentam no primeiro trecho dos cordões uma série de 4-6 constrições. Como a maioria dos Monostilifera (Friedrich 1938, p. 234) Ototyphlonemertes possue um único nervo dorsal. $\hat{E}$ verdade que pude vê-lo, com segurança, apenas em $O$. erneba, onde êle se dispõe, nos vários indivíduos, diversamente ao lado do vaso dorsal. De $O$. erneba vi a saída de nervos anteriores partindo dos gânglios cerebrais dorsais. As células ganglionares, dispostas em grupos que revestem a superfície dos gânglios, reencontram-se com o mesmo aspecto em tôda a extensão dos cordões laterais. Assemelham-se às células nervosas do órgão cerebral (Fig. 27, ce).

Orgãos sensoriais. Um par de estatocistos, de forma ovóide ou esférica, localizado na superfície dorsal do gânglio ventral, sempre presente, como característico fundamental da família Ototyphlonemertidæ. Os estatolitos podem ser formados por dois cristais $(O$. evelin $x)$, por três $(O$. erneba Fig. 22) ou por vários (O. brevis e O. parmula - Fig. 33).

Orgãos sensoriais laterais são sempre ausentes assim como também os olhos. 
Os órgãos cerebrais, já descritos de O. evelinæ (Corrêa 1948, p. 5), não existem em $O$. brevis e segundo o exíguo material disponível também em O. parmula. Em O. erneba (Fig. 27) são volumosos e semelhantes aos do Hoplonemertino Polistilifero Drepanophorus albolineatus Bürger (Scharrer 1941, p. 116). Ressaltam-se mais que os de $O$. evelinæ, e como êstes situam-se fora do cérebro. O poro cerebral (Fig. 26, po) abre-se de cada lado ao nível ântero-lateral do gânglio cerebral dorsal. O canal cerebral passa através da epiderme, membrana basilar, musculatura circular e longitudinal. É constituído por três partes diferentes : a externa bulbosa (t), com larga cavidade, a parte média de lume estreito $(\mathrm{m})$ e a interna, dilatada, maior que as demais, a região sensorial propriamente dita (r). A parte média pode ser subdivida em duas zonas, a externa de parede delgada e a interna com espessamento da parede. Ao redor da câmara sensorial há dois tipos distintos de células: umas grandes, externas, fortemente eosinófilas são as células glandulares do órgão cerebral (ci). As outras, pequenas, internas, as células nervosas do órgão cerebral (ce), que se assemelham às células ganglionares do cérebro. Enquanto que em $O$. evelinæ estas células formam um massiço na extremidade cega da câmara sensorial, em $O$. erneba elas constituem uma camada envoltória do epitélio da própria câmara. Este epitélio ciliado, assim como o das outras regiões do órgão cerebral é atravessado por tratos de secreção eosinófila, provàvelmente proveniente da camada de glândulas cerebrais externas. Entre a câmara sensorial e o gânglio cerebral dorsal há um conectivo de tecido nervoso (co).

Sulco cefálico transversal é presente em tôdas as espécies, sendo excepcionalmente nítido em $O$. erneba (Fig. 26, h), onde êle se destaca em duas faixas, uma dorsal, com o vértice voltado para a extremidade caudal e outra ventral, voltada para a extremidade cefálica.

Gonadas. Sexos separados. As gônadas masculinas e femininas estão lateralmente situadas na metade posterior do corpo. Como nenhuma das quatro espécies possue divertículos intestinais nítidos, as gônadas não são simétricamente dispostas em alternância com êles. Em O. brevis, os dutos masculinos são excepcionalmente largos enquanto que nas outras espécies são capilares. Ovócitos maduros de $O$. erneba são muito volumosos, medindo de diâmetro máximo $0,15 \mathrm{~mm}$.. Vários exemplares desta espécie mostraram gônadas femininas com os ovócitos degenerados.

Ocorrência. As espécies conhecidas de Otothyphlonemertes brasileiras são representantes da fauna bentônica. Habitam as micro-cavernas existentes entre os grãos de areia, de diâmetro variável, da zona das marés. Até agora foram encontradas apenas nas práias da Ilha de São Sebastião, $100 \mathrm{kms}$. a leste de Santos. Nas várias estadias feitas na referida ilha, em diversas épocas do ano, a espécie mais frequente foi $O$. brevis, secundada por $O$. evelinæ e $O$. erneba. De $O$. parmula foram encontrados até agora somente alguns exemplares em ponto algo distante do habitat mais abundante das três primeiras espécies. 


\section{6 - Summary}

1 - My histological study of nutrition in certain Polyclads (Corrêa 1949a) showed a preliminar and extra-cellular digestion in the main intestine. The latter is lined with numerous club-shaped cells of Minot, and these were thought to be responsible for the production of digestive enzymes (Bock 1925, p. 53-54). Preliminary experiments with these Turbellaria did not give univocal results.

In one of the species of Ototyphlonemertes (O. brevis Corrêa 1948) I verified a dense concentration of erythrophilous, probably glandular, cells in the first part of the gut, that I call "chamber of club-shaped cells" Already Böhmig (1929, p. 18, 64) compared these cells with the Minot cells of Turbellaria.

2 - I used worms of $O$. brevis fed in the laboratory and others preserved immediately after catching. In the state of fasting as well as in the various phases after ingestion the stomach (Figs. 1-2) does not show considerable modifications. Its epithelium is always villose and provided with two types of glands (es). Evidently this part functions as ingestive gut ("Einfuhrdarm") and does not partake in digestion. The following chamber of club-shaped cells (Fig. 3) contains high non-ciliated cells alternating with a great number of erythrophil clubs (g). The same type of cells occurs, although less numerous, in the rest of the mid-gut (Figs. 4-5), the intestine (s. str.).

Immediately after food has been taken into the gut the epithelium of the chamber becomes lower (Fig. 6). This is a symptom of secretion. Also the content of the clubs diminishes and the food in the lumen shows traces of digestion. In the further parts of the mid-gut (Fig. 9) the height of the columnar cells decreases still more and also that of the clubs. The food is not yet dissolved. The gut has alternately regions with food and without. This distribution of the material is effected by means of peristaltic and antiperistaltic movements during ingestion and digestion.

In the next stages (Fig. 10) the club-shaped cells advance towards the lumen of the chamber and become filiform. The food is disintegrated mechanically (Figs. 7-8) and begins to be dissolved chemically, as is shown by the commencement of the absorption of small granules into the columnar cells. In some cases the passage of red stained granules of the food into the intestinal epithelium (Fig. 12) could be seen; in others the content of the intestine is completely transformed into an amorphous mass. Only ingested algæ (Fig. 15, y) and cuticular elements of animal prey preserve their form; they are not digested. During the phases of absorption the columnar cells grow higher than the erythrophil ones and their surface becomes villose (Fig. 11). The absorved substances show very various aspects : droplets (Figs. 13-14), granules, and vacuoles of different size in the columnar cells.

At the end of absorption the club-shaped cells reassume the aspect of the fasting stage. The absorbed material has disappeared from the gut and the epithelium returns to its normal state. The phases may be resumed as : ingestion (Figs. 3-5) ; decrease in height of the epithelium by secretion 
(Figs. 6, 9) ; extracellular digestion (Figs. 7, 8, 12, 15) ; absorption and increase of the epithelium (Figs. 10,11, 13,14); distribution of the absorbed material and return to the resting phase.

3 - Before ingesting its food (Polychætes, Crustaceans) the Nemertean protrudes its proboscis (Fig. 19), seizes the animal and directs it towards its mouth (Figs. 16-17). The prey struggles, but is overcome by means of the stylet. During the engulphing movements the body of the worm changes its form continually (Fig. 20). When two or three worms compete for the same prey, they cannot swallow it whole as they generally do, but only suck out its contents. The worm does not feed longer than 30 minutes at a time.

I cut Nemertines (O. brevis) into three sections under the microscope. The first cut lay between oesophagus and stomach, the second behind the chamber of club-shaped cells. I united 12-15 fragments of the same region on a slide in a drop of sea-water and covered it with a slip. By slight pressure on the slip the contents of the cells were freed. Then I added a piece of striated muscle of Armadillidium vulgare Latr. to each drop.

The digestive function of the different sections was observed repeatedly for 24 hours (mean temperature $19^{\circ} \mathrm{C}$.). The results were always univocal : the slide with the chamber of club-shaped cells showed complete disappearance of the striation and liquefaction of the crustacean muscle after one hour. This effect is due to the erythrophil gland cells. Also the posterior sections of the guts digested, but less intensely. The anterior parts did not change during the whole time of the experiment. This corresponds to the histological distribution of the club-shaped cells. As a control I always prepared a slide with muscle fibres only. They were not changed in 24 hours.

4 - The obvious digestive function of the erythrophilous intestinal cells in Ototyphlonemertes contrasts with the diversity of opinions concerning the similar elements in Turbellarians, the club-shaped cells of Minot. I continue to consider the phylum Platyhelminthes as a natural unit and do not with Friedrich (1935) separate the primarily parenchymatic Turbellarians from the secondarily parenchymatic Nemerteans. On the other hand I do not intend to judge the function of the club-shaped cells in Turbellarians from my experiences with Nemertines. Phylogenetic evolution may also lead to change of function and not only to specialization (Remane 1948).

5 a - c - O. erneba, n. sp. (Fig. 26), is $10-12 \mathrm{~mm}$. long (O. evelinæ: $30 \mathrm{~mm}$. ; O. brevis : $10 \mathrm{~mm}$.) and $0,5 \mathrm{~mm}$. broad. The colour is whitish. The annular and longitudinal muscles $(\mathrm{mu})$ reach the tip of the head. Fibres of connective tissue that liken a skeleton connect the gut with the basal membrane of the epidermis. The parenchyma is amply developed as in brevis, where it even penetrates into the epithelium of the gut (Fig. 29, q).

The concentration of erythrophil glandular cells in the anterior part of the mid-gut that occurs in brevis (Fig. 3) does not exist in erneba. A cæcum is absent and excretory organs were not seen. The rhynchocœlom has half the length of the body (evelinx : $30 \%$; brevis : 20\%). The anterior chamber of the proboscis (a) is equipped with papillæ (Figs. 23-24, pa), each armed with a rhabdite. The central (u) and the accessory stylets (x) are smooth. 
The statolith (Fig. 22) is composed of three globules (evelinæ: two ; brevis : numerous). One pair of statocysts (against pallida pallida) and 3 globules forming the statolith distinguish erneba from pallida czerniavskyi, aurita suchumica, aurantiaca, duplex, macintoshi, and brunnea. The body of $O$. aurita aurita tapers towards the anterior and posterior end, whereas the diameter of the body of $O$. erneba is the same along the whole length except the head. The length of mature worms $(12 \mathrm{~mm}$.) separates erneba from claparède $i$ still immature with $30 \mathrm{~mm}$. $O$ spiralis Coe and $O$. pellucida Coe have spiral grooves on all stylets, absent in erneba. The papillæ in the anterior chamber of the proboscis also occur in $O$. parmula, but the latter has spiral grooves on the stylets and its statolith is composed of several globules.

O. erneba has a single dorsal nerve. Lateral sense organs are absent. The cerebral organs (Fig. 27) are well developed. A transverse cephalic furrow (h) surrounds the body behind the brain as in evelinæ and brevis. $O$. erneba was found together with these species in sand of the tidal zone on the island of São Sebastião.

O. parmula, n. sp. (Fig. 28) from sand of the island of São Sebastião, is distinguished from evelinx, brevis, erneba, and the valid species listed by Bürger (1904, p. 26-28) by the spiral grooves of the stylets (Figs. 30, 32). The statolith (Fig. 33) is composed of numerous globules ; the uncertain $O$. claparède $i$ has three. From $O$. spiralis and $O$. pellucida with spiral grooves on the stylets $O$. parmula is separated by the bulbous, not canalicular shape of the vesicle of the middle proboscidian chamber (Fig. 28, v). Further characters of parmula are : papillæ with rhabdites in the anterior chamber of the proboscis; absence of cerebral organs and of a cæcum.

Combining the results of my own studies with the anterior descriptions the following morphological characters of the genus Ototyphlonemertes can be summarized; of course many of them are not known from the older species :

Filiform animals, up to $50 \mathrm{~mm}$. long; head slender, without eyes, not demarcated from body. One or exceptionally two pairs of statocysts situated in nerve cell layer on dorsal surface of ventral ganglia. Dorsal ganglia strongly developed. Cerebral sense organs small or absent, situated anterior to brain. Lateral sense organs or a post-cerebral belt of glandfree cells may occur. Cephalic gland surrounding the rhynchodæum with short, thick tubes, sometimes not distinguishable from parenchyma. Annular and longitudinal muscle layers reach tip of head. Muscles fixing base of proboscis to longitudinal layer of body-wall form separate bundles, not a continuous precerebral septum. Mouth and proboscis opening united. Proboscis sheath limited to anterior half of body. Proboscis armed with slender central stylet and basis and two pouches with up to 6 accessory stylets each. Cæcum short or absent, not attaining brain. Sexes separate.

As the cæcum is wanting in the 4 brazilian species, these might be separated as a subgenus also peculiar by the gland-free postcerebral belt. 


\section{7 - BIBLIOGRAFIA}

Bock, S. 1925, Papers from Dr. Th. Mortensen's Pacific Expedition 1914-16. XXV Planarians. Parts. I-III. Vidensk. Medd. Dansk naturh. Foren. v. 79, p. 1-84 t. 1-2.a Köbenhavn. Böhmig, L. 1929, Nemertini. W. Kükenthal \& Th. Krumbach, Handb. Zool. v. 2, 1 Hälfte, p. 1 (3) - 110 (3). Berlin \& Leipzig (W. de Gruyter). Bresslau, E. \& Reisinger, E. 1928, Platyhelminthes. W. Kükenthal \& Th. Krumbach, Handb. Zool. v. 2, p. 34-51. Berlin \& Leipzig (W. de Gruyter \& Co.). Brinkmann, A. 1917, Die pelagischen Nemertinen. Bergens Museums Skrifter, n. ser. v. 3, no. 1 p. VIII + 194 t. 1-16. Kristiania. Bürger, O. 1895, Die Nemertinen, Faun. Flor. Golf. v. Neapel, Monogr. 22, XVI + 743 pp. 31 t. Berlin (R. Friedländer \& Sohn). 1904, Nemertini. Das Tierreich (Preuss. Akad. Wiss.) fasc. 20, XVII + 151 pp. 15 fig. Berlin (R. Friedländer \& Sohn). 1897-1907, Nemertini. Bronn's Kl. Ordn. v. 4 Suppl. VIII + 542 pp. 22 t. Leipzig (C. F. Winter). Claparède, R. E. 1863, Beobachtungen über Anatomie

wirbelloser Thiere. VIII + 120 pp. 18 t. Leipzig (W. Engelmann). Coe, W. R, 1940, Revision on the Nemertean Fauna of the Pacific coast of North, Central and Northern South America. Allan Hancock Pacific Exp., v. 2, no. 13, pp. 247-323, t. 24-31. Los Angeles (The University of Southern California Press.). 1943, Biology of the Nemerteans of the Atlantic Coast of North America. Transact. Conn. Acad. Arts \& Sciences v. 35 p. 129-328 t. 1-4. New Haven, Conn. Corrêa, D. D. 1948, Ototyphlonemertes from the Brazilian Coast. Com. Zool. Mus. Montevideo, v. 2 no. 49, p. 1-12 t. 1-2. Montevideo. 1949, Ecological study of Brazilian Ototyphlonemertes. Com. Zool. Mus. Montevideo, v. 3 no. 55, p. 1-7 t. 1. Montevideo. 1949a, Sôbre o gênero Zygantroplana, Bol. Fac. Fil. Ci. Letr. Univ. S. Paulo, Zoologia no. 14, p. 173-216 t. 1-5. S. Paulo. Du Plessis, G. 1891, Sur une nouvelle Oerstedia aveugle, etc. Zool. Anz., 14. Jahrg., p. 413-416. Leipzig. Friedrich, H. 1935, Studien zur Morphologie, Systematik und Oekologie der Nemertinen der Kieler Bucht. Arch. Naturgesch. N. F. v. 4 fasc. 3, p. 293-375. Leipzig. 1936, Nemertini. G. Grimpe, Tierwelt der Nord \& Ostsee, pars IV d, p. 1-69. Leipzig (Akadem. Verlagsges). 1938, Einige neue Hoplonemertinen aus der Ostsee. Kieler Meeresforschungen. v. 3 fasc. 1, p. 233-251. Kiel. Hyman, L. H. 1946, The nature of the eosinophilous spheres in the intestinal epithelium of Planarians : a correction. Transact. Amer. Microsc. Soc. v. 65 no. 3, p. 276-277. Menasha, Wisc. Keferstein, W. 1862, Untersuchungen über niedere Seethiere. Zeitschr. wiss. Zool., v. 12 (1863) fasc. 1 (1862), p. 1-147, t. 1-11. Leipzig. Marcus, E. 1949, Turbellaria Brasileiros (7) Bol. Fac. Fil. Ci. Letr. Univ. S. Paulo. Zool. no. 14, p. 7-155 t. 1-22. S. Paulo. Méhely, L. 1930, Ueber die Minotschen Drüsen der Planarien. Stud. Zool. v. 1 fasc. 3, p. 161-176, 2 t. Budapest (citado seg. Zool. Ber. v. 27, p. 95, ref. no. 338). Oxner, M. 1907, Quelques observations sur les Némertes de Roscoff et de Villefranche-sur-Mer. Arch. Zool. Expér. Génér., sér. 4, v. 6. Notes et Revue, no. 4, pp. LXXXII-LCII. Paris. Pérez González, M. D. 1949, Sôbre a digestão e a respiração das Temnocephalas (Temnocephala bresslaui, spec. nov.) Bol. Fac. Fil. Ci. Letr. Univ. S. Paulo. Zool. no. 14, p. 277-323 t. 1-4. S. Paulo. Reisinger, E. 1926, Nemertini. P. Schulze, Biol. Tiere Deutschl. pars 7, p. 1-24, 7 f. Berlin (Gebr. Borntraeger). Remane, A. 1926, Morphologie und Verwandtschaftsbeziehungen der aberranten Gastrotrichen. I. Zeitschr. Morphol. Oekol. d. Tiere v. 5. p. 625-754. Berlin. 1933, Verteilung und Organisation der benthonischen Mikrofauna der Kieler Bucht. Wiss. Meeresunters. Abtlg. Kiel, v. 21, pp. 161-221. Kiel. 1948, Die Theorie sprunghafter Typenneubildung und das Spezialisationsgeschehen. Naturwissensch, 35. Jahrg. fasc. 9, p. 257-261. Berlin \& Göttingen. Scharrer, B. 1941, Neurosecretion. III. The cerebral organ of the Nemerteans. Journ. comp. Neurol., v. 74, p. 109-130. Philadelphia, Pa. Stiasny-Wijnhoff, G. 1930, Die Gattung Oerstedia. Zool. Mededeel. v. 13, fasc. 3-4, p. 226-240. t. 7-9. Leiden. Vogt, C. 1851. Zoologische Briefe v. 1, 719 p. 925 f. Frankfurt a. M. (Literarische Anstalt, I. Rütten). Willier, Hyman \& Rifenburgh, 1925, A histo-chemical study of intracellular digestion in triclad flatworms. Journ. Morphol. Physiol. v. 40 p. 299-340. Philadelphia, Pa. Wilson, Ch. B. 1900, Habits and early development of Cerebratulus lacteus (Verr.). Quart. Journ. Micr. Sci. n. ser. v. 43, p. 97-198 t. 9-11. London. 


\section{8 - Estampas \\ EXPLICAÇÃO DAS LETRAS}

a, câmara anterior da proboscis.

b, cérebro.

c, cordão nervoso lateral.

ce, células nervosas do órgão cerebral.

ci, células glandulares do órgão cerebral.

co, conectivo nervoso.

d, diafragma.

e, epiderme.

ef, esôfago.

es, glândulas do estômago.

f, estômago.

g, células glandul ares eritrófilas.

ga, gânglio dorsal.

gc, glândulas cefálicas.

ge, glândulas do estilete.

gv, gânglio ventral.

$\mathrm{h}$, sulco cefálico transversal.

i, intestino.

j, gônada.

$\mathrm{k}$, base do estilete principal.

l, vaso lateral.

m, região média do órgão cerebral.

mt, músculos fixadores da tromba.

mu, musculatura do corpo.

$\mathrm{n}$, ovário.

o, órgão cerebral.

$\mathrm{p}$, câmara posterior da proboscis.

pa, papilas.

po, poro cerebral.

$q$, parênquima.

r, região sensorial do órgão cerebral.

ri, rincodeo.

$\mathrm{s}$, estatocisto.

t, região externa do órgão cerebral.

$\mathrm{u}$, estilete principal.

$\mathrm{v}$, vesícula bulbosa.

vd, vaso dorsal.

$\mathrm{x}$, estiletes accessórios.

y, algas no intestino médio posterior.

$\mathrm{z}$, placa caudal.

ESTAMPA 1

Ototyphlonemertes brevis - Fases digestivas.

Fig. 1 - Setor do estômago.

Fig. 2 - Setor do estômago.

Fig. 3 - Setor da câmara de clavas no estado jejuno.

Fig. 4 - Setor da parte anterior do intestino médio jejuno.

Fig. 5 - Setor da parte posterior do intestino médio jejuno. 


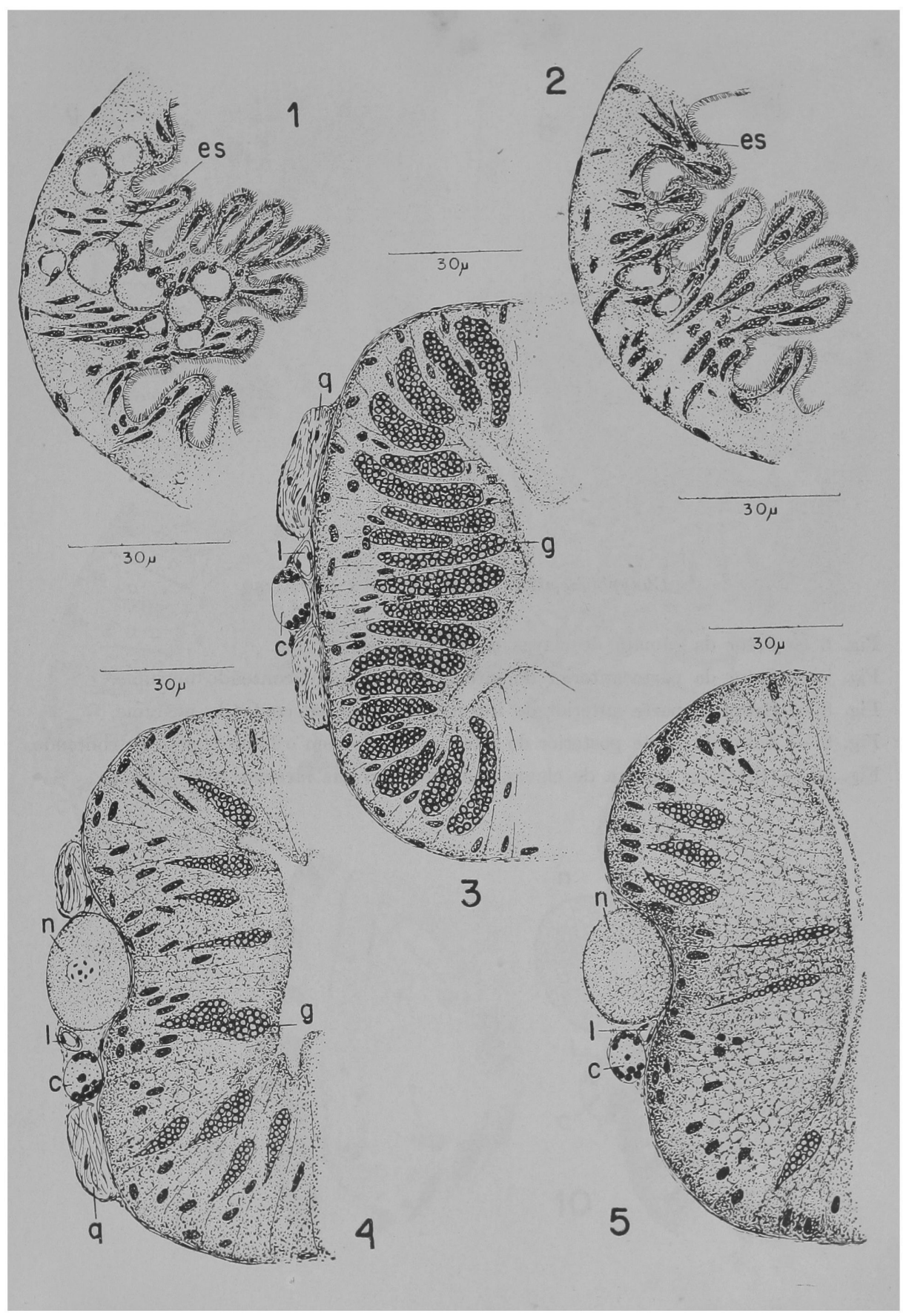


ESTAMPA 2

Ototyphlonemertes brevis - Fases digestivas.

Fig. 6 - Setor da câmara de clavas com conteúdo no lume.

Fig. 7 - Setor da parte anterior do intestino médio com conteúdo no lume.

Fig. 8 - Setor da parte anterior do intestino médio com conteúdo no lume.

Fig. 9 - Setor da parte posterior do intestino médio com o lume repleto de conteúdo.

Fig. 10 - Setor da câmara de clavas com projeção das mesmas para o lume. 


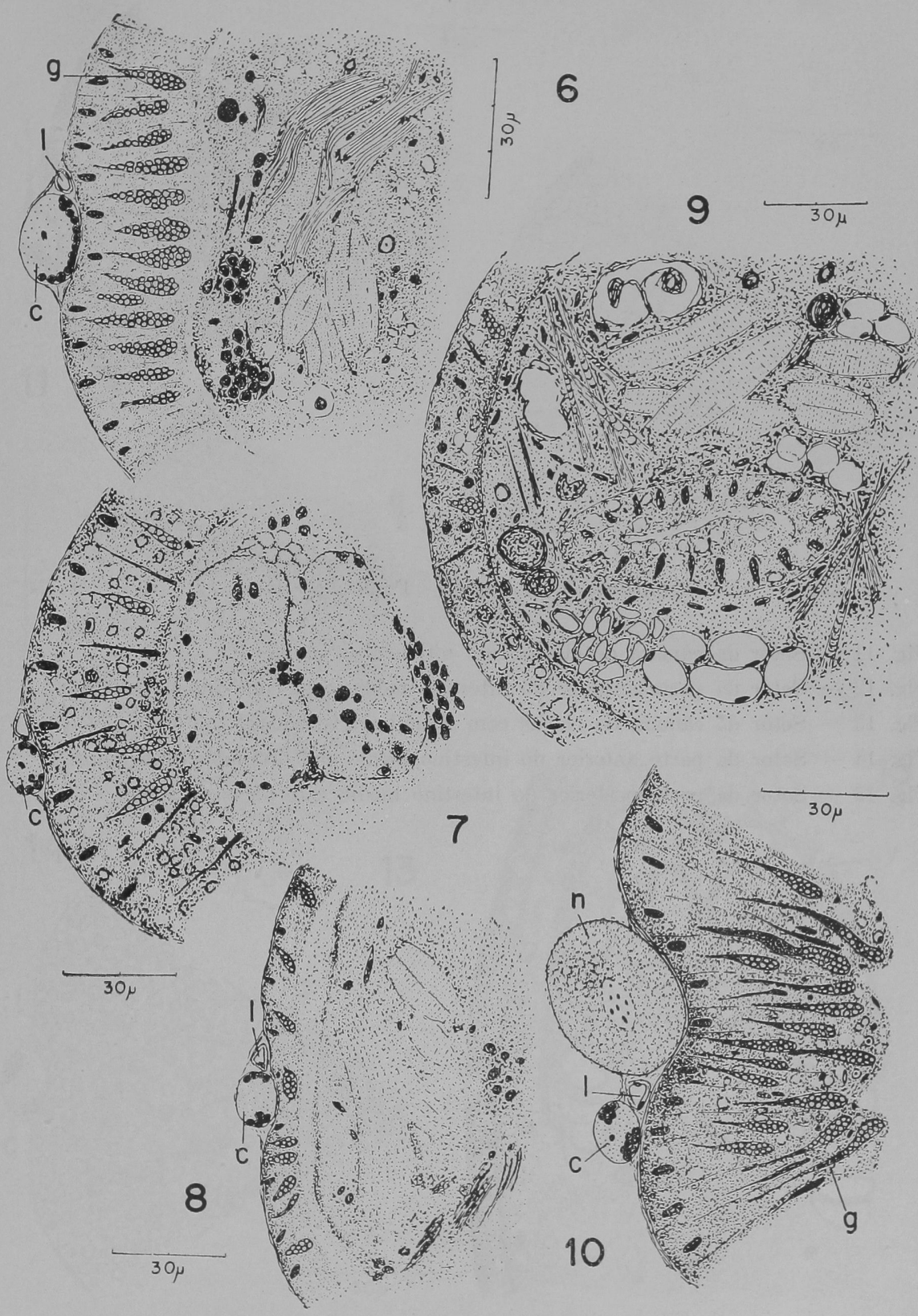




\section{ES'TAMPA 3}

Ototyphlonemertes brevis - Fases digestivas.

Fig. 11 - Setor da câmara de clavas com nítida absorção.

Fig. 12 - Setor da parte anterior do intestino médio com conteúdo no lume.

Fig. 13 - Setor da câmara de clavas com grânulos absorvidos.

Fig. 14 - Setor da parte anterior do intestino médio com grânulos absorvidos.

Fig. 15 - Setor da parte posterior do intestino médio com algas no lume. 


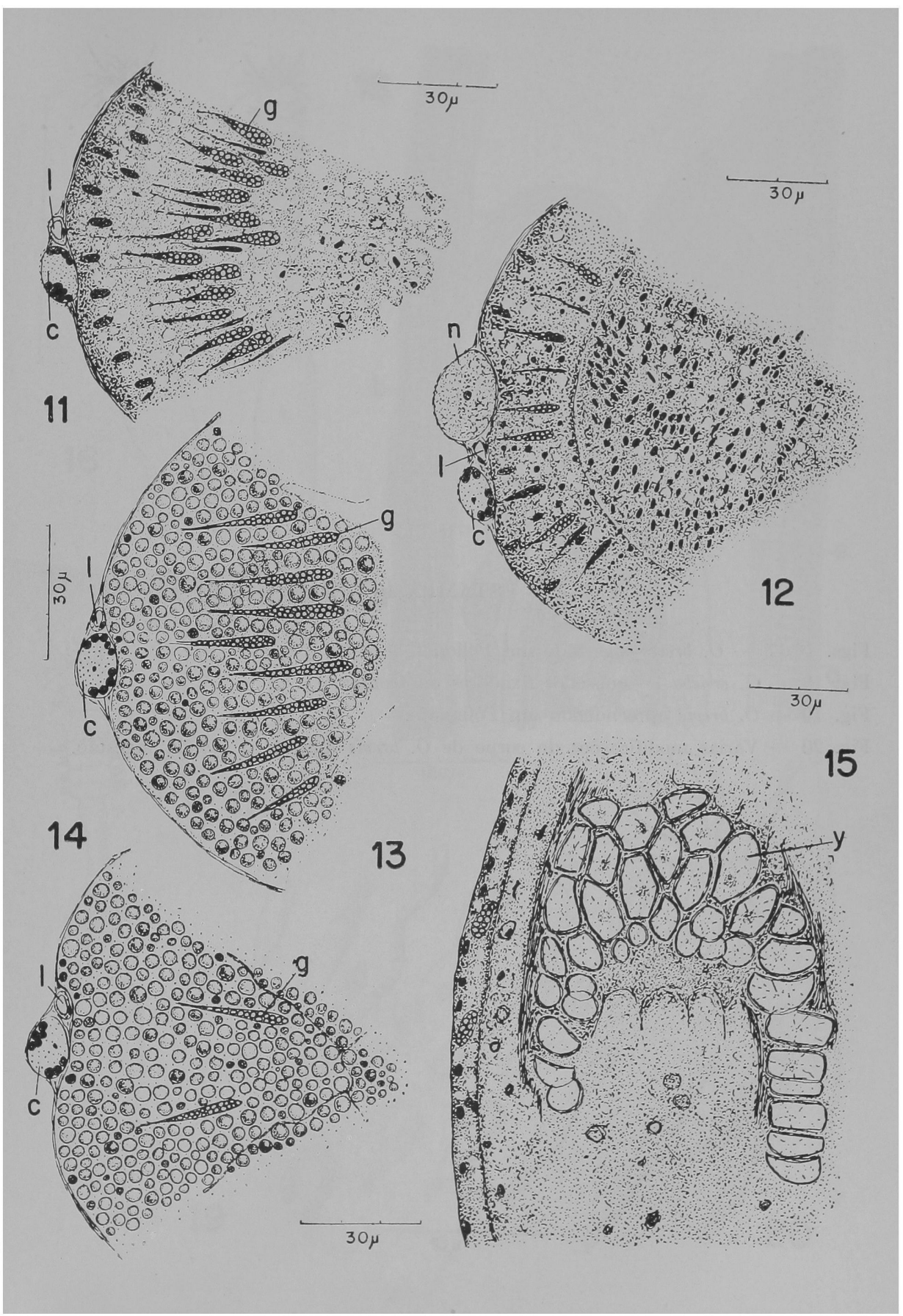




\section{ESTAMPA 4}

Figs. 16-17 - O. brevis ingerindo um Poliqueto.

Fig. 18 - O. erneba - músculos fixadores da tromba.

Fig. 19 - O. brevis apreendendo um Poliqueto.

Fig. 20 - Várias modificações do corpo de O. brevis durante o ato da ingestão. 


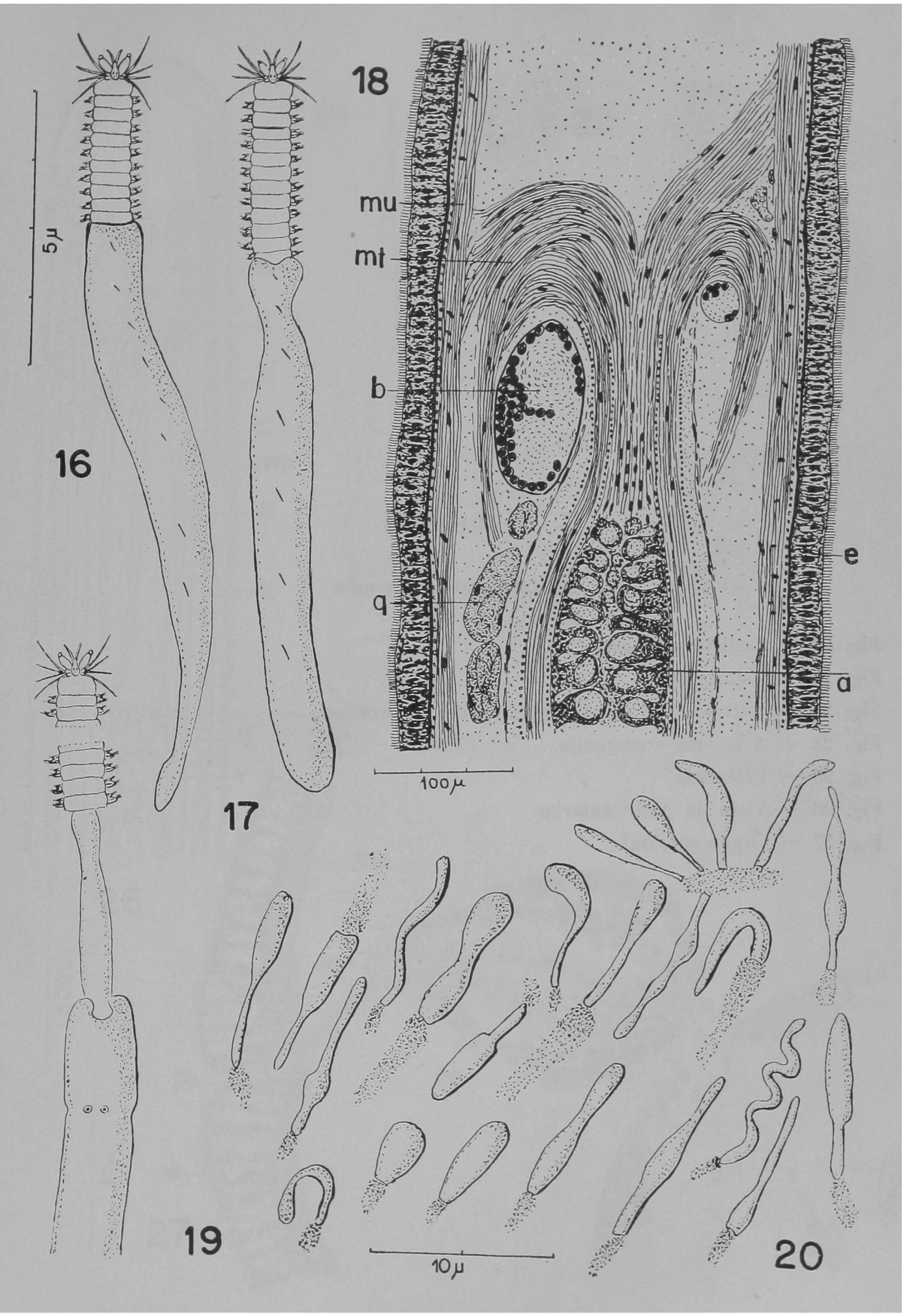


ESTAMPA 5

\section{Ototyphlonemertes erneba}

Fig. 21 - Estilete principal.

Fig. 22 - Estatocișto.

Fig. 23 - Extremidade da câmara anterior da proboscis.

Fig. 24 - A mesma aumentada.

Fig. 25 - Proboscis.

Fig. 26 - Vista da parte anterior.

Fig. 27 - Órgão cerebral. 


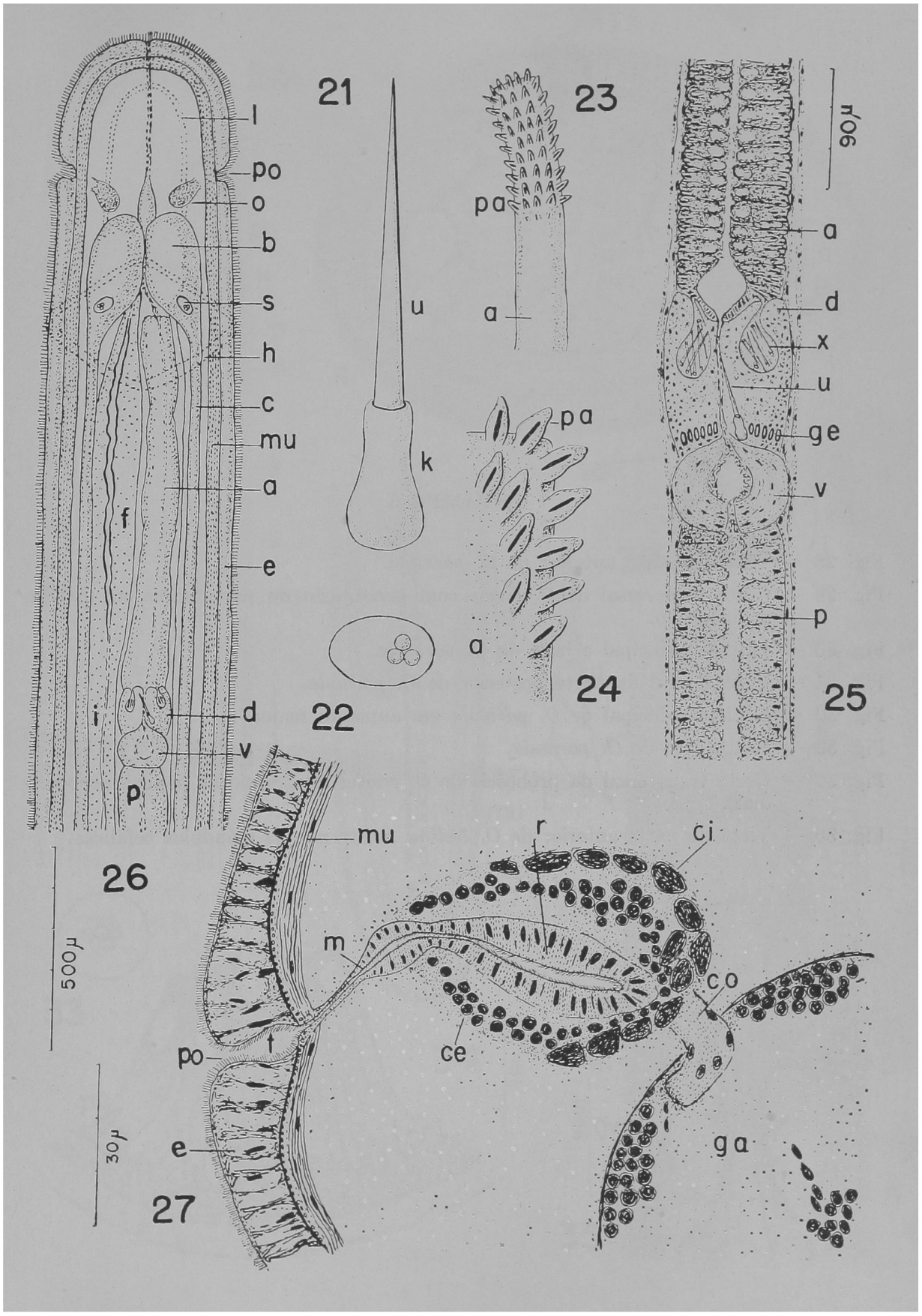


ESTAMPA 6

Fig. 28 - Vista da parte anterior de O. parmula.

Fig. 29 - Corte transversal de $O$. brevis com penetração do parênquima no epitélio do intestino.

Fig. 30 - Estilete principal e base de O. parmula.

Fig. 31 - Vista lateral da parte posterior de O. parmula.

Fig. 32 - Estilete principal de $O$. parmula em aumento maior.

Fig. 33 - Estatocisto de O. parmula.

Fig. 34 - Corte transversal da proboscis de O. erneba mostrando as papilas proboscidiais.

Fig. 35 - Vista da parte anterior de $O$. evelinæ mostrando as glândulas cefálicas. 


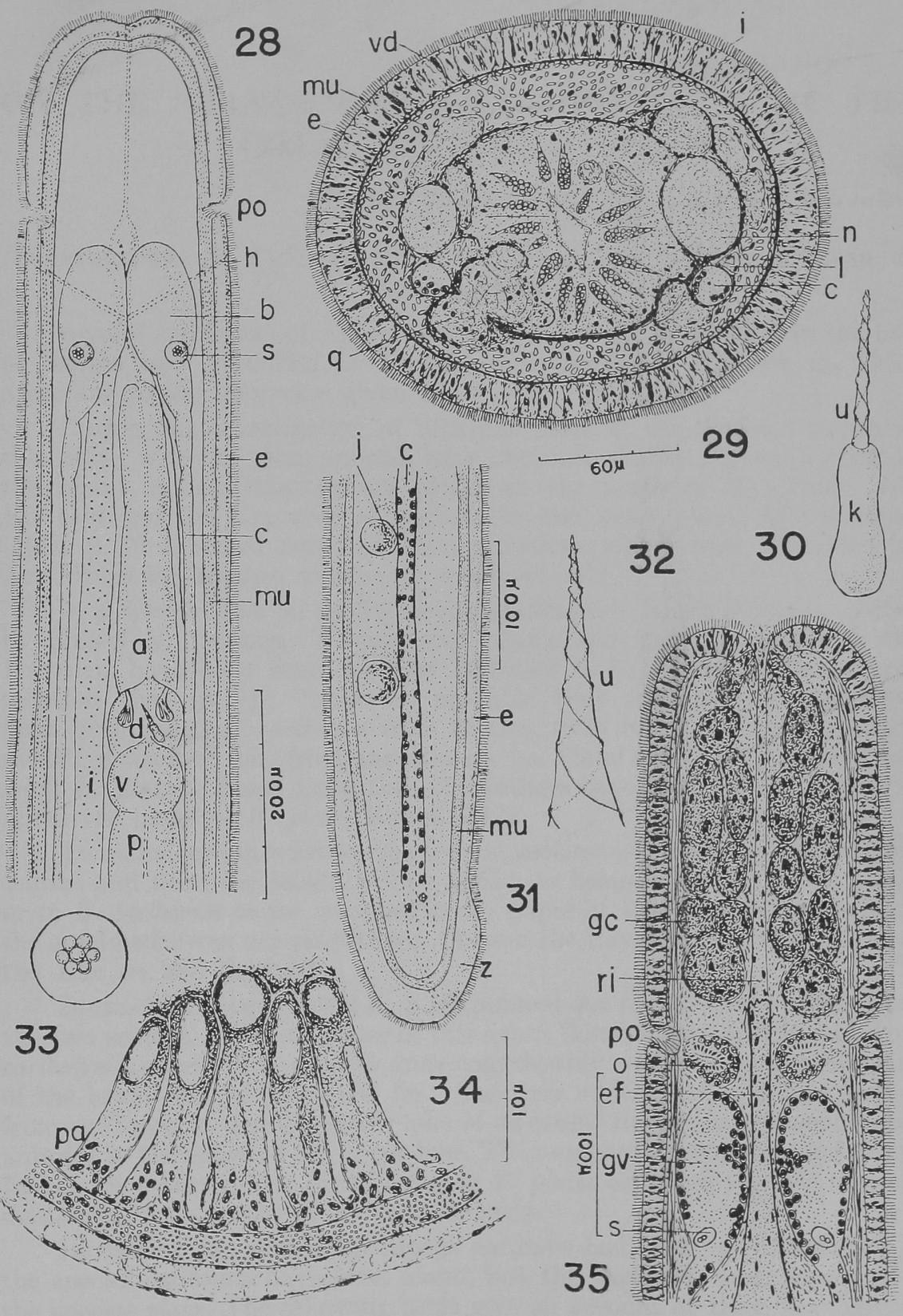


